\title{
THE GENETIC ORGANISATION OF NATURAL POPULATIONS OF LOLIUM PERENNE
}

\section{INFLORESCENCE PRODUCTION}

\author{
M. D. HAYWARD
}

Welsh Plant Breeding Station, Aberystwyth

Received 28.v.66

\section{INTRODUCTION}

THE present investigation examines the genetic basis of ecotypic differentiation in persistent populations of Lolium perenne L. In this species, as in grasses generally, persistency may be regarded as a function of the capacity for continued asexual reproduction (Langer, 1956; Breese, Hayward and Thomas, I965). Results on seed and seedling characters have already been presented (Hayward and Breese, I966). The evidence suggested an absence of selection pressure for efficiency of sexual reproduction in the populations and a consequent deterioration of the sexual process. Seedling characters generally showed a simple additive system of genetic variation but there were also indications of nuclear/cytoplasmic interaction. This has been taken as evidence in support of results obtained from the somatic selection experiments of Breese et al. (1965), which suggested that continued asexual reproduction may invoke systems of variability originating in the plasmon.

This paper discusses the genetic control of inflorescence production in these populations.

\section{MATERIAL AND METHODS}

The $10 \times 10$ diallel cross described by Hayward and Breese (loc. cit.) was planted out in the experimental field in the form of a randomised block with four replicates. Each of the 1oo families was represented by 15 plants per replicate.

The material was planted out in April 1963 and records were taken of the degree of inflorescence production in August of the same year. The date of inflorescence emergence was defined as the number of days after the first of May for all four replicates in 1964 and for two replicates only in 1965 .

\section{RESULTS}

\section{(i) Degree of inflorescence production}

The perennial forms of Lolium have varying inductive requirements in terms of low temperatures and short days before inflorescence initiation and development occur (Cooper, 1954). Variation in these requirements can be to some extent assessed by sowing seed under conditions where full inductive treatment will not be received, e.g. by 
sowing during late winter in a warm glasshouse, as in the present experiment. The response to such conditions will be manifest in two forms: firstly a plant either does or does not flower, and secondly, having flowered, the number of inflorescences produced may depend on the number of initials available in a receptive state at the time of treatment.

These two responses were recorded on the spaced plants in the field approximately eight months after sowing. The numbers of flowering plants were scored over all four replicates, whilst the number of inflorescences produced was counted on such plants in the first two replicates only. The results presented in table $\mathrm{I}$ are in the form amen-

TABLE I

$\mathcal{N}$ umber of flowering plants per family (upper values) and mean number of inflorescences produced (lower values)

\begin{tabular}{|c|c|c|c|c|c|c|c|c|c|c|}
\hline & I & 2 & 3 & 4 & 5 & 6 & 7 & 8 & 9 & Io \\
\hline I & $\begin{array}{l}34 \\
70\end{array}$ & $\begin{array}{l}3^{2} \\
4^{1}\end{array}$ & $\begin{array}{l}35 \\
44\end{array}$ & $\begin{array}{l}52 \\
77\end{array}$ & $\begin{array}{l}37 \\
49\end{array}$ & $\begin{array}{l}42 \\
64\end{array}$ & $\begin{array}{l}33 \\
44\end{array}$ & $\begin{array}{l}11 \\
5^{6}\end{array}$ & $\begin{array}{l}35 \\
32\end{array}$ & $\begin{array}{l}36 \\
69\end{array}$ \\
\hline 2 & $\begin{array}{l}39 \\
83\end{array}$ & $\begin{array}{l}30 \\
73\end{array}$ & $\begin{array}{l}25 \\
57\end{array}$ & $\begin{array}{l}37 \\
94\end{array}$ & $\begin{array}{l}19 \\
70\end{array}$ & $\begin{array}{l}43 \\
88\end{array}$ & $\begin{array}{l}29 \\
44\end{array}$ & $\begin{array}{l}31 \\
29\end{array}$ & $\begin{array}{l}25 \\
65\end{array}$ & $\begin{array}{l}34 \\
92\end{array}$ \\
\hline 3 & $\begin{array}{l}4 \mathrm{I} \\
62\end{array}$ & $\begin{array}{l}44 \\
58\end{array}$ & $\begin{array}{l}3^{8} \\
77\end{array}$ & $\begin{array}{r}57 \\
149\end{array}$ & $\begin{array}{l}53 \\
84\end{array}$ & $\begin{array}{l}57 \\
69\end{array}$ & $\begin{array}{l}5 \mathrm{I} \\
92\end{array}$ & $\begin{array}{l}4^{0} \\
35\end{array}$ & $\begin{array}{l}49 \\
70\end{array}$ & $\begin{array}{l}53 \\
97\end{array}$ \\
\hline 4 & $\begin{array}{r}52 \\
118\end{array}$ & $\begin{array}{l}47 \\
90\end{array}$ & $\begin{array}{r}50 \\
105\end{array}$ & $\begin{array}{r}50 \\
116\end{array}$ & $\begin{array}{l}48 \\
87\end{array}$ & $\begin{array}{l}53 \\
92\end{array}$ & $\begin{array}{l}52 \\
59\end{array}$ & $\begin{array}{l}45 \\
69\end{array}$ & $\begin{array}{l}42 \\
83\end{array}$ & $\begin{array}{l}4^{8} \\
7^{1}\end{array}$ \\
\hline 5 & $\begin{array}{l}32 \\
92\end{array}$ & $\begin{array}{r}47 \\
105\end{array}$ & $\begin{array}{l}41 \\
88\end{array}$ & $\begin{array}{l}54 \\
7 \mathrm{I}\end{array}$ & $\begin{array}{l}25 \\
3^{2}\end{array}$ & $\begin{array}{l}45 \\
64\end{array}$ & $\begin{array}{r}44 \\
102\end{array}$ & $\begin{array}{l}3 \mathrm{I} \\
57\end{array}$ & $\begin{array}{l}42 \\
70\end{array}$ & $\begin{array}{l}47 \\
57\end{array}$ \\
\hline 6 & $\begin{array}{l}30 \\
55\end{array}$ & $\begin{array}{l}55 \\
90\end{array}$ & $\begin{array}{l}55 \\
95\end{array}$ & $\begin{array}{l}40 \\
92\end{array}$ & $\begin{array}{l}51 \\
82\end{array}$ & $\begin{array}{l}45 \\
9^{1}\end{array}$ & $\begin{array}{l}5^{6} \\
74\end{array}$ & $\begin{array}{l}4 \mathrm{I} \\
82\end{array}$ & $\begin{array}{r}53 \\
108\end{array}$ & $\begin{array}{l}39 \\
56\end{array}$ \\
\hline 7 & $\begin{array}{l}4^{\mathrm{I}} \\
99\end{array}$ & $\begin{array}{l}3^{8} \\
22\end{array}$ & $\begin{array}{l}47 \\
{ }_{5}^{8}\end{array}$ & $\begin{array}{r}59 \\
153\end{array}$ & $\begin{array}{l}4{ }^{\mathrm{I}} \\
59\end{array}$ & $\begin{array}{l}55 \\
75\end{array}$ & $\begin{array}{l}4^{8} \\
71\end{array}$ & $\begin{array}{l}48 \\
8 \circ\end{array}$ & $\begin{array}{l}44 \\
52\end{array}$ & $\begin{array}{l}36 \\
72\end{array}$ \\
\hline 8 & $\begin{array}{r}31 \\
105\end{array}$ & $\begin{array}{l}41 \\
63\end{array}$ & $\begin{array}{l}45 \\
64\end{array}$ & $\begin{array}{l}54 \\
67\end{array}$ & $\begin{array}{l}31 \\
67\end{array}$ & $\begin{array}{l}51 \\
96\end{array}$ & $\begin{array}{l}41 \\
42\end{array}$ & $\begin{array}{l}42 \\
58\end{array}$ & $\begin{array}{l}43 \\
80\end{array}$ & $\begin{array}{l}33 \\
31\end{array}$ \\
\hline 9 & $\begin{array}{l}33 \\
83\end{array}$ & $\begin{array}{l}29 \\
43\end{array}$ & $\begin{array}{l}5^{0} \\
7^{8}\end{array}$ & $\begin{array}{l}43 \\
32\end{array}$ & $\begin{array}{l}43 \\
64\end{array}$ & $\begin{array}{l}44 \\
49\end{array}$ & $\begin{array}{l}42 \\
57\end{array}$ & $\begin{array}{l}5_{71}^{5} \\
\end{array}$ & $\begin{array}{l}30 \\
45\end{array}$ & $\begin{array}{l}53 \\
54\end{array}$ \\
\hline I0 & $\begin{array}{l}39 \\
64\end{array}$ & $\begin{array}{l}52 \\
99\end{array}$ & $\begin{array}{l}5^{6} \\
68\end{array}$ & $\begin{array}{l}59 \\
{ }_{96}\end{array}$ & $\begin{array}{l}44 \\
68\end{array}$ & $\begin{array}{l}51 \\
89\end{array}$ & $\begin{array}{l}48 \\
88\end{array}$ & $\begin{array}{l}5^{1} \\
77\end{array}$ & $\begin{array}{l}44 \\
80\end{array}$ & $\begin{array}{l}56 \\
74\end{array}$ \\
\hline
\end{tabular}


able to the now familiar analysis of a diallel table as outlined by Hayman (1954). The analysis of variance for both characters is presented in table 2. As the error variances were homogeneous when assessed

TABLE 2

Analysis of variance of the diallel tables for number of plants flowering and number of inflorescences produced

\begin{tabular}{|c|c|c|c|c|}
\hline Item & $\mathrm{N}$ & $\begin{array}{l}\text { Number of plants } \\
\text { flowering } \\
\text { M.S. }\end{array}$ & $\mathrm{N}$ & $\begin{array}{c}\text { Number of flowers } \\
\text { produced } \\
\text { M.S. }\end{array}$ \\
\hline$a$ & 9 & II $5 * * *$ & 9 & $709 * * *$ \\
\hline $\begin{array}{l}b_{1} \\
b_{2} \\
b_{3}\end{array}$ & $\begin{array}{r}\mathbf{1} \\
9 \\
35\end{array}$ & $\begin{array}{l}26 * \\
\text { I } 5^{* * *} \\
\text { I } 2 * * *\end{array}$ & $\begin{array}{r}\text { I } \\
9 \\
35\end{array}$ & $\begin{array}{c}23 \\
99 \\
23^{*}\end{array}$ \\
\hline$b$ & 45 & I $3 * * *$ & 45 & $204^{*}$ \\
\hline $\begin{array}{l}c \\
d\end{array}$ & $\begin{array}{r}9 \\
3^{6}\end{array}$ & $\begin{array}{c}26 * * * \\
8 * *\end{array}$ & $3^{9}$ & $\begin{array}{l}3^{6} 7^{* *} \\
233^{*}\end{array}$ \\
\hline Blocks & 3 & $66 * * *$ & I & $47^{8}$ \\
\hline Pooled error & 297 & 5 & 99 & I 38 \\
\hline
\end{tabular}

by Bartlett's test $\left(\chi_{5}^{2}=4 \cdot 9 ; \mathrm{P}=0 \cdot 5 \cdot 0 \cdot 3\right.$ and $\chi_{5}^{2}=9 \cdot 4 ; \mathrm{P}=0 \cdot 1-0 \cdot 05$ for numbers of flowering plants and number of inflorescences produced) the main effects have been tested against the pooled error.

The analyses reveal that there is good evidence of additive genetic variation between the populations for both characters (item $a$ ). The nature of the dominance variation (item $b$ ), however, is not consistent for the two characters. The mean dominance item $\left(b_{1}\right)$ is significant for the number of plants flowering but not for the number of inflorescences produced. This situation also applies to the $\left(b_{2}\right)$ mean square measuring asymmetrical gene distribution. The $\left(b_{3}\right)$ item is however significant for both characters. The two remaining items $(c)$ and $(d)$, measuring average and specific reciprocal effects, are both significant revealing the participation of the maternal (or plasmon) component in the control of these two responses. In view of the magnitude of the reciprocal effect, the additive and dominance components must be interpreted with caution since, when compared with either of the reciprocal mean squares only the $(a)$ mean square for the number of plants flowering retains its significance. On this basis, therefore, it would appear that the mean squares measuring dominance are no greater than, and might indeed be no more than a reflection of, recip- 
rocal differences. It must be remembered, however, that this test is of somewhat dubious validity when applied to the present sampling situation (see Wearden, I964).

\section{Physiological relationships in inflorescence production}

The two characters considered are a reflection of variation in the underlying physiological mechanism controlling flowering. Cooper (loc. cit.) has suggested that three stages are involved, each stage showing different responses to environmental conditions. The stages are:-

(i) Attainment of competence of the shoot apex. = Inductive phase.

(ii) Initiation of the inflorescence under the appropriate photoperiod.

(iii) Elongation and differentiation of the inflorescence.

The perennial forms of Lolium generally require exposure of the shoot apex to low temperature for varying periods before the attainment of competence. Initiation follows at photoperiods of $13-14$ hours or longer, with subsequent differentiation and elongation being controlled by temperature. The present experiment has revealed varying requirements for competence in that the number of plants heading differed for the various populations. This, of course, assumes that the environmental conditions after induction are adequate for the second and third stages. As the number of plants flowering was not determined until August, it is unlikely that photoperiod or temperature were limiting factors (see Cooper, I957). The correlation between the number of plants flowering and the date of inflorescence production is negative and highly significant $\left(r_{98}=-0.44^{* * *}\right)$, confirming the principle that early flowering plants have low inductive requirements before attaining competence (Cooper, ig6o).

It might be expected that the number of inflorescences produced would be a reflection of the number of apices available at the time of the inductive treatment. An indication of this relationship can be obtained from the correlation between the number of inflorescences and the number of leaves (in the axils of which must be the receptive shoot apices) at the time of the inductive treatment. This correlation of leaf number some 33 days after sowing (see table 6, Hayward and Breese, I966) with the number of inflorescences produced, calculated on a family mean basis, is negative $\left(r_{98}=-0.28 * *\right)$ suggesting that some other factor is operating in these populations.

The populations studied all derive from old permanent pastures which have been subjected to varying grazing intensities (see Breese and Charles, I964). Where grazing pressure is high, Cooper (1959) has proposed that selection will favour genotypes with a high rate of tillering and an associated high winter requirement for induction. This may be examined by considering the relationship between the 
number of plants which flower and a management rating based on the intensity of grazing, as proposed for these populations by Breese and Charles (loc. cit.). The correlation for the ten parental families is positive and significant $\left(r_{8}=+0.72 * *\right)$, confirming that populations from heavily grazed habitats have a high inductive requirement. Hence, one may consider that, where grazing intensity is high, vegetative reproduction is at a premium, and therefore selection will favour genotypes with a low degree of inflorescence production. Associated with infrequent flowering there may well be a general degradation of the sexual process. A possible indication of this can be obtained from consideration of the system of variability controlling inflorescence production where full inductive requirements have been met. The date of inflorescence appearance in the second and later years of growth will next be considered in this context.

\section{(ii) Date of inflorescence emergence}

The date of heading, as measured by the day on which at least three inflorescences have emerged from the leaf sheath, is a compound character reflecting the cumulative effects of the three stages outlined in the previous section.

Data for the two years are presented in table 3, with the corresponding analysis of variance in table 4 . The residual item of the analysis is the pooled sum of squares of the interactions of the main effects with blocks accumulated over the two years. These interactions were homogeneous when compared by Bartlett's text $\left(\chi_{5}^{2}=6 \cdot 5\right.$, $\mathrm{P}=0 \cdot 3-0 \cdot 2)$. All of the main items are significant when compared with this residual mean square. Here again the importance of the maternal component must be emphasised for, compared with either of the $(c)$ or $(d)$ mean squares, only the $(a)$ mean square is significant.

The relative proportion of the maternal (i.e. average reciprocal) effect to the total variation can be estimated from the components of the mean squares. From the analysis of variance the value is 20 per cent., whilst the corresponding estimate of the additive genetic component is 34 per cent. This latter value may be considered as an estimate of heritability in the narrow sense, although, of course, the maternal component will influence any expected response to selection based upon this value.

Turning to the second part of the analysis over the two years, the highly significant years-item reflects the difference between the two seasons, since the mean date of inflorescence emergence in 1964 was 26 th May and nearly a week later, 3 rd June, in r $_{965}$. The significance of the interaction items provides evidence of the flexibility of the control over the two environments. Most affected over years are the average reciprocal effects $(c)$ which barely achieve significance when tested against the corresponding item measuring interaction with years. This would suggest that special conditions within years invoke different effects. 
TABLE 3

Mean date of inflorescence emergence for 1964 and 1965 , upper and lower values respectively

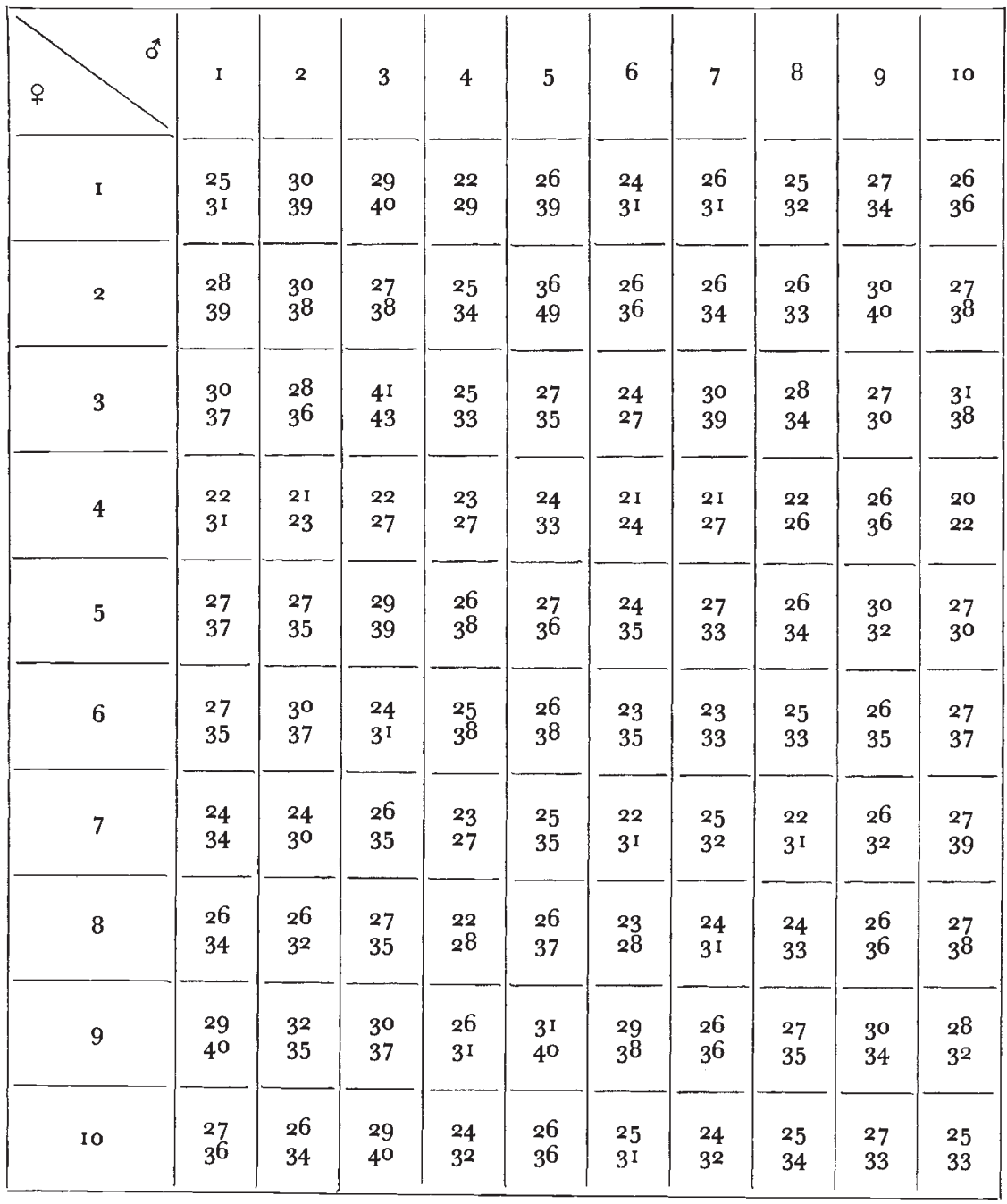

A fuller understanding of the mode of action of the system underlying the reciprocal effects can be obtained from application of the analysis developed by Durrant ( 1965$)$. Two basic forms have been recognised; alpha inheritance, where a constant effect is added to, or subtracted from, all the members of an array, and beta inheritance, where there are changes in the dominance relationships of reciprocal crosses. The test of significance of the $(c)$ item against the $(d)$ in the main part of the analysis of variance in table 4 reveals the presence of alpha type inheritance, together with its interaction with years from the second part of the analysis. Where many factors contribute to alpha inheritance, an indication of their summed effects on array $P n$ 
TABLE 4

Analysis of variance of the mean date of inflorescence emergence

\begin{tabular}{|c|c|c|c|}
\hline Item & $\mathrm{N}$ & Mean squares & Variance ratio \\
\hline$a$ & 9 & $35^{6}$ & $85 \cdot 37^{* * *}$ \\
\hline $\begin{array}{l}b_{1} \\
b_{2} \\
b_{3}\end{array}$ & $\begin{array}{r}1 \\
9 \\
35\end{array}$ & $\begin{array}{l}3 \cdot 0 \\
21 \cdot 0 \\
26 \cdot 28\end{array}$ & $\begin{array}{l}<1 \\
\quad 5.04^{* * * *} \\
\quad 6 \cdot 30^{* * * *}\end{array}$ \\
\hline$b$ & 45 & $24 \cdot 71$ & $5 \cdot 92^{* * *}$ \\
\hline c & 9 & 64 & ${ }^{1} 5.35^{* * *}$ \\
\hline$d$ & $3^{6}$ & $20 \cdot 30$ & $4 \cdot 87^{* * *}$ \\
\hline Years & I & $8_{45^{1}}$ & $1947^{* * *}$ \\
\hline $\mathrm{Y} \times a$ & 9 & 16 & $3 \cdot 84^{* * *}$ \\
\hline $\begin{array}{l}\mathrm{Y} \times b_{1} \\
\mathrm{Y} \times b_{2} \\
\mathrm{Y} \times b_{3}\end{array}$ & $\begin{array}{r}I \\
9 \\
35\end{array}$ & $\begin{array}{l}0 \cdot 30 \\
7 \cdot 55 \\
6 \cdot 90\end{array}$ & $\begin{array}{c}<1 \\
1 \cdot 81 \\
1 \cdot 65\end{array}$ \\
\hline $\mathrm{Y} \times b$ & 45 & 6.88 & $\mathrm{r} \cdot 65^{*}$ \\
\hline $\mathrm{Y} \times c$ & 9 & $22 \cdot 88$ & $5 \cdot 49^{* * *}$ \\
\hline $\mathrm{Y} \times d$ & 36 & $5 \cdot 77$ & $1 \cdot 83^{* *}$ \\
\hline Blocks within years & 4 & $2 \mathrm{I}$ & $5 \cdot 03$ \\
\hline Pooled error & 396 & $4 \cdot 17$ & \\
\hline
\end{tabular}

can be obtained from the quantity $a$. The least squares estimates of these $a$ values are derived from:-

$$
\begin{gathered}
a_{1}=\frac{1}{\mathrm{n}} \quad \mathrm{G}_{1} \\
\mathrm{G}_{1}=\mathrm{Y}_{1} \cdot-\mathrm{Y} \cdot 1
\end{gathered}
$$

where $Y_{1}$. and $Y_{{ }_{1}}$ are the totals of the male and female array values of parent $P_{1}$ respectively. The values of $a$ for the two years are pre- 
sented in graphical form in fig. I. Deviations from the line of unit slope indicates the relative interaction with years. It can clearly be seen that population 3 is mainly responsible for the interaction.

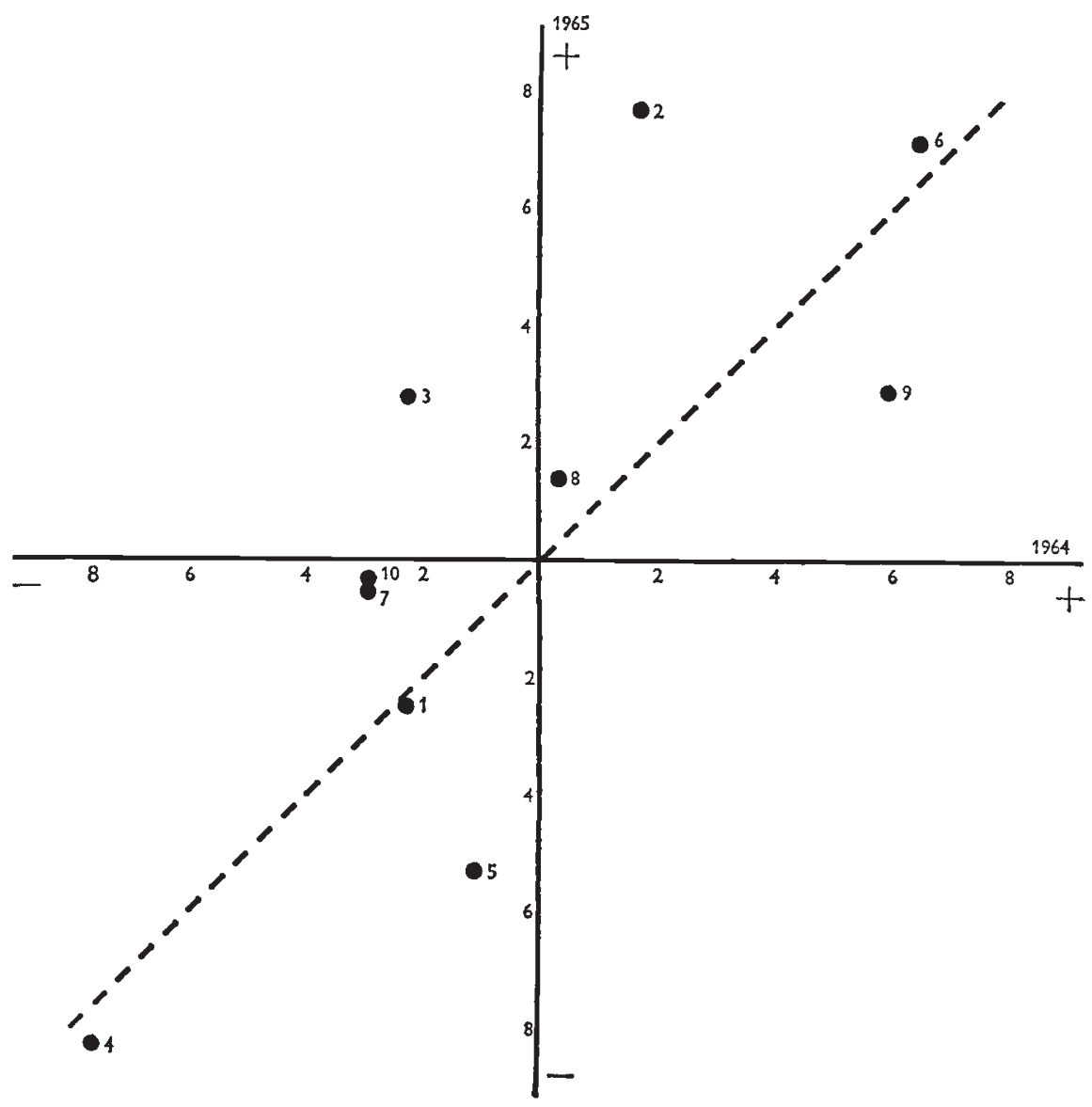

FIG. I.-Graph of $a$ values for the timing of inflorescence appearance.

The overall direction of the reciprocal effect can be assessed from the relationship of $\Sigma a P^{\prime}\left(P^{\prime}=\right.$ corresponding parent value measured as the deviation from the overall parental mean). If positive, as it is in the present case $\left(\Sigma a P^{\prime}=+728\right)$ the trend is in a maternal direction. Thus the female has the general effect of delaying the timing of inflorescence appearance.

As alpha inheritance is the main component of the reciprocal effect, the male and female array values may be corrected by addition or subtraction of the appropriate $a$ value and parental values may thus be adjusted in either of two ways. In view of this, any further analysis based on the relationships of parental and $F_{1}$ values, such as the $W r / V r$ analysis of Jinks and Hayman (1953) will be somewhat ambiguous (see Durrant loc. cit.). 


\section{DISCUSSION}

The present series of experiments has revealed the existence of genetic variation between the populations for inflorescence production. Cooper (I954) examined flowering in several Lolium species, and drew the general conclusion that although the character was under polygenic control, it behaved as a threshold character since inflorescence production only occurred in those individuals in which the cumulative effects of genotype and environment exceeded a certain minimal level.

The production of inflorescences during the seeding year clearly behaves as a threshold character since only a certain proportion of the plants within a family produced flowers in response to the limited exposure to low temperatures and short days. As Cooper (loc. cit.) has discussed, the ability to respond to low temperatures is the underlying variate, the character appearing only in those plants which have attained competence of the shoot apex.

In consideration of the genetic control of the three stages of inflorescence production outlined by Cooper (loc. cit.), the results here provide information on the first stage and on a combination of the second and third stages; the experimental design does not allow for a separation of these latter stages.

The number of plants producing inflorescences during the seeding year is a measure of the attainment of competence. The second and third stages of flowering may each invoke a separate genetic system, their final product however being the cumulative character, date of inflorescence appearance. Inflorescence initiation in pasture forms of Lolium perenne L. appears to occur under photoperiods of $13-14$ hours or longer, with subsequent differentiation and elongation controlled by temperature. Variation in the control of the response to these critical environmental conditions will be reflected in the timing of inflorescence appearance. As all genotypes flowered during the first and second harvest years, it would appear that the natural photoperiod and temperature regime was not a limiting factor in inflorescence production. Hence the data on the number of plants flowering during the seeding year can safely be assumed to represent variation in the attainment of competence. The control of this variation is mainly additive with very little indication of non-additive genetic effects; there is however an indication of maternal control.

A similar pattern of control applies to the timing of inflorescence appearance in the first and second harvest years. Here, however, the maternal component is of much greater importance.

Turning to consider the number of inflorescences produced during the seeding year, it is not known whether this character is a reflection of the number of apices available at the time of the inductive treatment, or whether other physiological factors, such as the transfer of a flowering hormone, are involved. The correlation between the number of leaves at the time of receiving the necessary environmental 
treatment for competence and the number of inflorescences produced was negative, suggesting that floral production was not dependent on the number of apices present.

A further facet of this problem is revealed by the correlation between the degree of inflorescence production and grazing pressure on the swards from which the populations were derived. Genotypes from heavily grazed pastures have a high inductive requirement and an associated low degree of flowering, i.e. selection has favoured vegetative reproduction. It may well be that the past selective history of the population in relation to selection for or against sexual reproduction is the important factor to be considered. Irrespective of the physiological relationships which may exist here, the picture for the genetic control is again basically an additive system together with an important maternal component.

\section{Population structure}

In Lolium, the system of genetic variation controlling the timing of inflorescence appearance can, according to Cooper (r959), be modified by the action of two main ecological factors. As a result of examination of heading in the three strains Wimmera, Irish and Kent ryegrasses he proposed that any variation could be accounted for by climatic and agronomic factors. In Wimmera for instance, the limitations of the growing season have selected for the annual habit in relation to the local conditions of temperature and photoperiod. In Irish ryegrass, where the emphasis is on seed production during the first harvest year, early flowering is limited purely by spring temperatures, with a wide range of acceptable photoperiods. In Kent ryegrass, the commercial variety originates from heavily grazed permanent pastures, with very infrequent seed crops. As such, selection has been primarily for vegetative reproduction and, in association with this, for a late date of flowering, a concomitant of a high winter requirement.

The series of populations under examination all derive from permanent pastures distributed over a very small area of the Monmouthshire moors. Gross climatic effects of rainfall and photoperiod will be common to the whole area, thus differences in inflorescence production may be related to the different management systems imposed. Breese and Charles (1962) demonstrated a close correlation between the date of inflorescence appearance and a management rating based on the intensity of grazing for the twenty-three populations of the original collection. A similar relationship applies to the present ten populations which form a representative sample. Here the correlation is negative $\left(r_{8}=-0.8 \mathrm{I}^{* *}\right)$ indicating that populations from pastures continuously grazed tend to be later than those from fields periodically cut for hay.

If sexual reproduction in old-established swards is unimportant, then the timing of inflorescence emergence might be expected to have significance only in so far as it determines the growth rhythm. On 
this premise, Hayward and Breese (1964) explained the apparent high dominance and interaction revealed by a half-diallel-cross (without reciprocals) as evidence of disruptive selection of nuclear genes under different sward managements. The present results from a full diallelcross show that these effects are no greater than, and indeed may be no more than a reflection of, a high maternal component. They emphasise the importance of reciprocal crosses in genetic studies of material of this nature. More specifically however, they indicate that in plant material, where asexual regeneration figures prominently, differentiation might be a consequence of change at the extra-nuclear level (see Breese et al., 1965 and Breese, 1966).

\section{SUMMARY}

I. The genetic basis of ecotypic differentiation for inflorescence production was examined in ten natural populations of Lolium perenne L. (see Hayward and Breese, 1966).

2. The pattern of variation between populations for the production of inflorescences during the year of sowing was mainly an additive system together with an important degree of maternal control. This variation could partly be related to ecological factors, such as grazing intensity.

3. A similar system of control applied to the timing of inflorescence appearance after full inductive requirements had been met. Evidence is also presented for the interaction of the control, particularly the maternal component, with the two seasons for which data is available. The reciprocal effects are due mainly to alpha type inheritance acting in a maternal direction, i.e. delaying the date of inflorescence emergence.

4. The results are discussed in relation to the known ecology of the populations and to their past history of selection for vegetative reproduction.

Acknowledgments.-I wish to thank the Director of the Welsh Plant Breeding Station, Professor P. T. Thomas, for his interest in this work and to Dr. E. L. Breese for his helpful advice and criticism.

\section{REFERENCES}

BREESE, E. L. 1966. Reproduction in ryegrass. Paper presented to Conference on "Reproductive Biology and Taxonomy of Vascular Plants". B.S.B.I. BReESE, E. L., AND CHARLES, A. H. 1962. Population studies in ryegrass. Rep. Welsh Pl. Breed. Stn, 1959, 30-34.

BREESE, E. L., haYWARD, M. D., AND thomas, A. c. 1965. Somatic selection in perennial ryegrass. Heredity, 20, 367-379.

COOPER, J. P. 1954. Studies on growth and development in Lolium. IV. Genetic control of heading responses in local populations. F. Ecol., $4^{2}, 521-55^{6}$.

COOPER, J. P. 1957. Developmental analysis of populations in the cereals and herbage grasses. II. Response to low-temperature vernalisation. F. agric. Sci., $49,3^{61-38}$. 
COOPER, J. P. 1959. Selection and population structure in Lolium. I. The initial populations. Heredity, 13, 31 7-340.

COOPER, J. P. 1960. Short day and low temperature induction in Lolium. Ann. Bot. Lond., N.S., 24, 232-246.

DURrant, A. 1965. Analysis of reciprocal differences in diallel crosses. Heredity, $20,573-608$.

HAYMAN, B. I. 1954. The analysis of variance of diallel tables. Biometrics, Io, 235-244.

hayward, M. D., AND BReEse, E. L. 1964. Population studies in ryegrass. Rep. Welsh Pl. Breed. Stn., I963, 33-36.

HAYWARD, M. D., AND BREESE, E. L. 1966. The genetic organisation of natural populations of Lolium perenne. I. Seed and seedling characters. Heredity, 2I, 287-304.

Jinks, J. L., AND hayman, B. I. 1953. Analysis of diallel crosses. Maize Genetics Co-operation News Letter, 27, 48-54.

LANGer, R. H. M. 1956. Growth and nutrition of timothy (Phleum pratense). I. The life history of individual tillers. Ann. appl. Biol., 44, 166-187.

WEARDEN, s. 1964. Alternative analyses of the diallel-cross. Heredity, I9, 669-68o. 